\title{
The Profits from Weapons and Troops in Iraq War 2003: The Real Reason for the World Financial Crises 2008
}

\author{
Momtchil Dobrev-Halachev ${ }^{1} \&$ Mariola Garibova $^{1}$ \\ ${ }^{1}$ Scientific Research Institute Dobrev \& Halachev. JSC., Sofia, Bulgaria \\ Correspondence: Momtchil Dobrev-Halachev, Scientific Research Institute Dobrev \& Halachev. JSC., P. O. Box \\ 101, 1404 Sofia, Bulgaria. E-mail: lordprmdobrev@ gmail.com
}

Received: October 19, 2017

Accepted: January 5, 2018

Online Published: February 20, 2018

doi:10.5539/ijef.v10n2p159

URL: https://doi.org/10.5539/ijef.v10n2p159

\begin{abstract}
Lord prof PhD Momtchil Dobrev-Halachev developed 2008 "Theory of generating of crises" and 2001 "Theory of the mafia". Based on these two theories, this paper explane the establishment of the financial crises 2008 all over the world.
\end{abstract}

Keywords: crise, mafia, corruption, theory, finance

\section{Introduction}

In the year 2008 Lord Prof. Momtchil Dobrev developed the "Theory of generating crises". The theory of generating crises has been developed by analyzing all the relationships between countries, and analyzing the causes and consequences of crises. The theory examines all possible options for generating crises. The theory ultimately leads to the conclusion that each crisis begins on the basis of a conscious action, whether of a state, of a government, of financial circles, of a president of one or more countries, of financial actors, of the financial market, stock markets, financial institutions, private interests.

All the factors that triggered the financial crisis in all over the world 2008, the conditions of neoliberalism, globalization that helped the crisis.

This paper gave the proofs for the reasons of the financial crises 2008 all over the world based on the Momtchil Dobrev's "Theory of generating ofcrises" and Momtchil Dobrev's "Theory of mafia". The paper also described the real reasons for the start of the financial crises 2008.

\subsection{Introduce the Problem}

The problem of the emergence and cause of the global financial crisis in 2008 is very important. The resolve of the causes of the financial crisis in 2008 is vital for our entire civilization. The research which is based on Momchil Dobrev's Theory of Crisis Generation gives a different view of the causes and consequences of the emergence of the global financial crisis in 2008. Here is the view of Momchil Dobrev that the basis for the cause of the global financial crisis in 2008 is the available and free money since 2003 to 2008 from the profits of weapon selling and selling in arms and the financing of the Iraq war in 2003. The reason for the crises in 2008 based on the Momtchil Dobrev theory of generating of crises is the profits from the purchasing of weapons, service, the investment in a war, and the war support in Iraq 2003. The conclusions of Momchil Dobrev are relevant here, based on his theories of generating crises, which prove that there is a clear connection and the track record of the profits from the arms trade and the organization and maintenance and support of the Iraq war in 2003. Here, it is important to conclude that the profit rate in the arms business and hence the generalized flaw in the whole process of preparing and implementing the war in Iraq are important conclusions that explain the causes of the global financial crisis in 2008.

Practical data on manufactured and sold arms for the Iraq war 2003 Maintaining the war, serving the war in Iraq in 2003 provide good evidences for this hypothesis, which is a treatise on Momchil Dobrev's Theory of Helicopter Crisis that free money from profits in arms and business for the Iraq war in 2003. and which profits is good and practical evidence.

The importance of revealing the real and real causes of the global financial crisis in 2008 is of great importance for our entire civilization. This is important in order to be able to anticipate and track such processes and take 
real measures to prevent such crises.

Preventing, tracking and preventing such crevices is important for the stability of financial, economic, social, public structures, the stability of individual states, entire continents, economic alliances.

To solve the problem of the real causes of the global financial crisis, according to Momchil Dobrev, it is necessary to analyze the volume of arms sales, auxiliary equipment, money for servicing the troops, and the whole process of financing the war in Iraq in 2003. What profits are made by the whole process and from there as a result of the available free money in the global financial markets. What is the profit rate in the trade and sale of arms, weapon and equipment from which to deduce the available free money from this process. All these analysis proves the hypothesis of Momchil Dobrev, which hypothesis is based on the theory developed by Momchil Dobrev - Theory of Crisis Generation.

The thesis of Lord Prof. Dr. Momchil Dobrev is that the real causes of the financial crisis in 2008 is the accumulated money from the profit from the sale of weapons and equipment and the financing of the war in Iraq. This thesis rests on the conclusions of Lord Prof. Dr. Momchil Dobrev based on the amount of money spent on financing the war in Iraq and the rate of profit from the sale of weapons, ammunition, equipment, war maintenance - clothing, equipment, foods.

The conclusions of Lord Prof. Dr. Momchil Dobrev rely on his experience and knowledge of the norm of profit in the trade of weapons, ammunition, food, equipment and clothing and military support in one war.

So far no one in the world has looked at the dependence of free money generated and profits on profits and the investment of these free money in construction and such derivatives and instruments.

\section{Research Methods}

To prove his thesis that the 2008 financial crisis is caused by the profits generated by the profit from the financing of the war in Iraq, Lord Prof. Dr. Momchil Dobrev is stepping on his theory of crisis generation, data and information on how much the financing of the the war in Iraq by the United States.

The research methods are the analysis of the weapon production all over the world before the war in IRAQ explore, analysis of the costs on a war, analysis of the profit from the weapon business and huge free money the profits of this business - the real reason for the crises 2008 the return of these money - the reduction of these money in construction, a highway balloon of free availability from the sale of weapon the identified war in Iraqinvested in the construction where the rule of profit is heavy and it for 1,5-2 years' analysis of the differences of the war in Iraq situation and data of the war in Iraq, analysis of available of corruption and the mafia all over the world, analysis of the crises environment - neoliberalism and globalization and political model of the mafia in government in Iraq.

\subsection{Analysis of the Costs in a War on the Example of Different Wars all over the World}

The WAR is the source of the greatest profits. An attack of war imposes and requires that it be funded, both with creatures and with production. The process includes banks, financial institutions, arms business companies, the military industrial complex, and not the political mafia.

As a result of each war, there is an economic crisis, a production crisis, an industrial crisis, a social crisis, a social crisis. These crises must be funded, where the aggressor is usually replaced by the aggressor, who owes money for years to the war and his presence, redistributes wealth, draws mostly from profits.

Profits the aggressor derives in all areas of development of a country or region.

WARS in which the United States has participated and created military conflicts.

The war in Mexico in 18401 cost \$ 2.4 billion

The ratio to the Gross Domestic Product of 1847 amounted to $14 \%$.

The Second World War costs about \$ 4.1 trillion or 36\% of GDP in 1945.

By the Second World War, almost the entire military budget of the country was spent on participating in military conflicts. The US spends 1.1\% of GDP on 1899 for the Spanish-American war and 1.5\% on defense spending.

The Second World War costs over $\$ 4.1$ trillion in which 400,000 American fighters died. US participation in the Second World War began on December 8, 1941.

The wars in Iraq and Afghanistan cost over $\$ 4.1$ trillion.

Third is the Vietnam War. The US spent \$ 738 billion or 2.3\% of the country's GDP in 1968. 
For the past 10 years, the US has spent between $\$ 3.7$ and $\$ 4.4$ trillion

\subsection{Analysis of the Profit from the Weapon Business and the Real Norm of Profits in This Weapon Business}

The profit from the weapon business and huge free money - the profits of this business - the real reasons for the crisis 2008 - the return of these money - the reduction of these money in construction. A highway balloon which is free in the global world.

The macroeconomics does not take into account - what is the profit rate. Whether this profit rate is invested back and in what size and share, and more importantly, in what industry.

All revenues and savings are treated in a variety of industries one by one - That does the weak.

Moreover, there are schemes to lawfully conceal profits - through so-called offshore companies.

In the different branches of the economy, they have different rates of profit.

So in the military production sector, the profit rate ranges from $30 \%$ to $70 \%$.

It's the lucky winner with the highest profit rate.

The light industry is about $5-10 \%$.

Food industry 15 - 25 percent.

But also as a relative volume and as a total volume sales of weapons and ammunition are the largest.

Here are the wrong conclusions of the macroeconomics about a given state of the planet's economy.

Here are the wrong conclusions about the consequences.

A distinction must be made between which sectors are state-owned and which industries dominate private companies.

The Pentagon's spending on wars in Iraq and Afghanistan is \$ 1.6 trillion. And this means that the profit rate is from 30 to 70 percent for different weapons, equipment and ...

Let's make things simple - that's 800 billion dollars of sour money for investment.

Where - in the closest and fastest returns in the industries.

Where id invested the profit from Cocaine? In construction of buildings!!.

Money laundering of drugs and weapons goes through construction.

Here the reversibility terms are shorter and the renown is the fastest - 18-22 MONTHS. The profit rate is from 300 to higher.

The cost of the world for the period 2004 - 2008 for sale of military equipment amounts to 114, 338 trillion US dollars.

For the US, this is $\$ 34.9$ billion for 2008 alone - $\$ 6.159$ billion.

For Russia, 28.536 billion dollars, respectively - only for 2008 - 5.953 billion dollars.

For Germany - 11,450 million dollars - for 2008 - 2,837 billion dollars

For France - 9.607 billion dollars - for 2008 alone - 1.585 billion dollars

For the British, - \$ 5,132 billion - for 2008 alone - \$ 1,075 billion.

Sales data of the two largest nations is as follows:

For the US

2004 - 6.648 billion

$2005-6.786$ billion

$2006-7,394$ billion

$2007-7.914$ billion

$2008-6,159$ billion

For Russia

$2004-6,353$ billion

2005 - 5.485 billion 
$2006-6,186$ billion

2007 - 4,559 billion

2008 - 5,953 billion

For the 2007 military sales in current calls, the ten are the following in the world

1). Boeing USA

2). BAE Systems - 29,850 billion

3). Lockhead Martin

4). Northrop Grumman USA

5). General Dynamics USA

6). Raytheon USA

7). EADS

8). L-3 Communications USA

9). Finmeccanica - Italy

10). Thales France

Among the top 100 companies - 45 are from the United States, 32 are from Europe, 10 from Great Britain, 8 from France, 4 from Italy, 5 from Germany, Russia from 7 companies from Japan and South Korea from 4 companies from Israel and India from 3 companies.

The top 100 companies for 2007 - a total sale of $\$ 346.9$ billion. For 2006 there is $12 \%$ nominal growth.

Countries bought the most weapons for 2004-2008, they are:

1). China - 12.980 billion dollars

2). India - $\$ 8.186$ billion

3). United Arab Emirates - 7,105 billion

4). South Korea - 6,921 billion

5). Greece - $\$ 4.813$ billion

\subsection{The Balloon of the Free Availability of Profits from the Sale of Weapon Based on the High Norm of Profits}

The balon of free availability of profits from the sale of weapon is the reason for the financial crises 2008 .

The investment of this profit in the construction. The normal profit in constructions is heavy and it makes for 1.5 - 2 years over $300-1000$ percent additional profit.

The war in Iraq provides an investment of \$411 million every day

The cost of the war in Iraq is actually between $\$ 3$ trillion and $\$ 4.4$ trillion.

The war began on March 20, 2003, when England and the United States attacked by air, land and sea, backed by Australia, Denmark, Poland, Spain

On March 6, 2003, inspectors published a report stating that they believe that Iraq, with its emerging economy and level of development, is in a position to develop or support a program to develop weapons of mass destruction.

On the other hand, the United States has several times suggested that al-Qaeda has terrorist training camps on Iraqi territory and that Saddam Hussein himself is financially helping her. Al-Qaeda's Rod-Osama bin Laden firmly denies that,

Every second of a war in IRAQ costs $\$ 5,000$,

In 2001 year, the financial sector becomes more powerful, more profitable and more concentrated. There are five investment banks, two financial conglomerates, three re-rating agencies and three insurance companies.

Businesses Build for Trillion US Dollars from Mortgages is initially normally structured.

Under the new scheme, when lending a property, lenders sell the mortgages of the envy banks, Investment Bankers combine thousands of mortgages and loans and create complex derivatives called structured bond issues. 
Investment banks then sell SEE to investors. Thus, when the borrower pays the mortgage, the money goes not to the lender but to the investors from all over the world.

In 2001, George Bush, a junior, comes to power in the United States, and this year, the financial sector has become much more profitable and more successful. At the heart of this prosperity are five investment banks, two financial consortia, three rating agencies, and three insurance companies.

As a result, end-to-end balances and associated system of over $\$ 5$ trillion of mortgages are available.

\section{What this system is about?.}

After the mortgage loan is given, it is sold through the mortgage of investment banks. On the other hand, investment bankers combine hundreds of thousands of mortgages as derivatives. They carry the assigned structured bond issues. Then, the investment bankers sell these companies to investors.

After all, Antico is not interested in the quality of these mortgage packages - not even the bankers

The objective is: a reduction of free money that contributes and makes huge profits for its own owners, subsequently buying up the banks they know a priceless, and so on.

Investment banks pay rating agencies of high EA rating and receive AAA rating. This creates the balon.

The creditors do not care if they will get their money back and start giving credit.

Investment banks earn money, rating agencies are not interested - they get money from banks. And they are not interested in the quality of mortgages. In this way, banks give out more credits. In fact, hundreds of billions go through this system.

Becomes a boom of construction, Builders begin construction mass reassure without the danger that buildings will remain empty.

Between 1996 and 2006, prices rose twice.

Companies such as Lehman Brothers and Goldman Sachs increase their assets from 30 billion to over 800 billion a year. Overall, the earnings of the EuroList are a bill of billions of dollars.

On the other hand, AIGG as the largest insurance company sells a large number of derivatives - credit swaps.

An investor who buys an EOU pays credit swaps and the money goes to AIG.

So they are insured. With derivatives, everyone can insure someone else's property.

If the value begins to fall to AI, it must recover the losses. But unlike ordinary insurances, speculators can buy swaps for papers they do not own. The right of many people to build up your property and so the losses will be as much money as possible for loss, and instead pay big bonuses to insurers involved a successful deal. Credit swaps are not adjusted. This allows AIG to not allocate money for potential losses. So the London office issues insurance.

Rating agencies earn four times more than AAA ratings for these papers. Moody's, SEP and Fitch win mills. Moody's quadrupled his profits from 2000 to 2007.

In March 2008, Bank Bear Stearns went bankrupt and\% Jay Morgan Chase bought it by giving two dollars a share. The Federal Reserve supports the deal and gives a 30 billion dollar loan. Instead of taking risk mitigation measures, the Federal Reserve gives this loan,

On October 4, 2008, President Bush signed a $\$ 700$ billion aid bill.

The indebtedness becomes 33 to 1 ,

Free money is invested in construction because the rate of profit there is the highest. Real drugs and money from wars and weapons are invested in construction.

This balon is created.

\subsection{Analysis of the Differences of the War in Iraq Situation and the Data of the War in Iraq}

$\$ 5000$ for every second $\$ 411$ million every day

Current spending per month is $\$ 12.5$ billion.

Costs reach 25 billion a month. The estimated price will be $\$ 3$ trillion.

The cost of the war is 3.7-4.4 trillion dollars in 10 years.

The Cost of War - Watson International Studies Institute at Brown University. 
The cost of the war is funded with a cumulative deficit - which should also cover interest rates. - In addition, the Pentagon has received extra between $\$ 326$ and \$ 652 billion out of the money directly to finance military action.

For internal security, $\$ 401$ billion is spent.

In addition, troops in Iraq and Afghanistan have filed additional claims of \$ 32.6 billion for disability and treatment.

Veteran compensation costs will increase from 598 to 934 billion dollars.

The cost is from 2.9 trillion to 3.6 trillion dollars.

George Bush - Congress allocates an extra 120 billion dollars

The IRAK war begins on March 20, 2003, when the United States and the United Kingdom attack air, land and sea. Supported by Australia, Denmark, Poland and Iceland.

Without the declaration of the Security Council of ONP to legalize the invasion.

2.5 Analysis of the Crisis Environment - Neoliberalism and Globalization and the Political Model of the Mafia in Government in Iraq

Neoliberalism across the globe leads to the globalization of the world economy. There is a cyclical nature of production and crises are preserved. Crises become more and more honorable. Crises are getting harder to overcome.

Progressive technologies are developing and there is a strategic superiority of certain countries over the rest of the world.

Globalization has led to the full exploitation of small peoples by the great peoples. The Neolibrasylama and globalization are bringing the peoples closer together, but they are actually moving away from them, and the real enslavement of one country in relation to others. They are approaching the near-developing countries, which makes the respective crisis immediately affecting all the other countries that are in this industrial and other development. Smaller countries are affected by lagged lag and in smaller degrees.

Countries in the world are not at the same level of development either industrially, and spiritually and culturally.

In neoliberalism, the world and domestic markets are the main driver of economic development.

Different countries have different levels of economic development. The different degree of competitiveness.

The economies of developed countries produce cheaper, produce more and better quality and thus impose their output and thus conquer the markets of the smaller, less developed countries. This is a process of pardoning poverty.

Neoliberalism raises in a natural way using the political system and political parties to impose a financial oligarchy. The financial oligarchy governs the governments and, respectively, the states.

The intertwining of financial interests and politics in turn generates not only the financial oligarchy but also the corruption and mafia in the state at all levels.

The financial oligarchy, the big corporations also hold the state elite.

In neoliberalism, there can not really be a civil encyclopedia and a robbery to control the government.

In fact, governments are creating such laws to protect certain corporate interests, support tactics, enforce and legitimate corrupt practices, enforce laws that exclude real civil society, genuinely enforce laws to legalize mafia in governments, and financial mafia.

In fact, governments are creating and adopting laws that legitimize thefts, corruption, mafia, and work in the state.

The media are conquered by certain corporations that govern governments and the state.

The media really can not fulfill their function.

Indeed, manipulation in favor of the financial and oligarchic mafia is done by the media, which prevents other thinking, memory, impose corruption and the mafia as a way of livelihood, governance, organization of society.

The media are heavily dependent on oligarchs and the oligarchic mafia.

The oligarchic mafia manages governments, and thus the whole states. 
THE goal is globalization to become controlling - which the oligarchic mafia will not allow Niko|Ga.

There is no specialization of a particular country to compete in other countries.

Necessary specialized and controlled globalization.

Consumers' society is only in the interest and profitable only for developed countries.

In this way, they place their goods and services in the consulates for a long period of time.

The generation of the crisis through the Iraq war is a result of the biggest premises in the artificial business, money that is invested in construction.

Globalization and Neoliberalism in Support of the Excessive Capital Excess helps this process.

\subsection{Analysis of Availability of Corruption and the Mafia all over the World}

The elements of the Momtchil Dobrev D. "Theory of the Mafia" and the political model of Mafia in Europa and for example in Greece.

In this part we will consider the basic elements, the relationships in the theory of mafia seen in the last 20 years in the experience of the author in connections of the given situation all over the world.

The below is the short description of the theory of the mafia, the vision of the author for creating the theory of the mafia. Its building and life and related also to the 2008 crises.

Behind the basic elements of the theory of the mafia are described also concrete appearances.

Elements of the Theory of the mafia are the following:

Structure of the mafia. It includes structures that they depend of the formula of the mafia.

Structural subordination. This is available also for the outside structure most described as organizational criminal group, also for the inside structure - this is a structure of state power, executive power, justice power.

Functional subordination. This type of subordination of members, and others is valid also for the inside structures - the structures in the state, justice and etc. Also for the outside structure - mostly in mafia structures.

The structures of the mafia are: outside structure - for the criminal groups, and inside structures - for the state, justice, execution power.

The availability of the mafia action is the condition of availability of ORDER/ The order will be executed based on:

\section{- subordinations - structural and functional.}

- on benefit cooperation * inside and outside.

Types of the mafia: inside juridical mafia, inside prosecutor mafia, mafia in the state, mafia in the municipalities, outside prosecutor mafia, outside juridical mafia, outside state mafia. There are procedures of taking in law orders of the mafia in the court, prosecutor office, state and etc.

\section{Formula of the Mafia}

The most simple model of the mafia which describes the factors which influence about the amount, type, and etc. of the mafia is the following:

MAFIA = Power $/$ state and etc. $/$ + Influence + Connections + Interests + ORDER/ORDERS + Mafia structure/ inside or outside/ + Monopolity Rigths+ laws/ rules/ practices/procedures + possibility of taking an alternative decision - obligation - responsibilities - morality/ethics.

The mafia is available also for the public and private sector. The power of the mafia and the corruption practices in Greece in the public sector are very stark.

The Mafia price is the material or non-material benefits of members of the above mentioned structures. Here is the connection between the mafia and the corruption.

\section{Sphere spread of the mafia all over the world.}

The mafia in Greece can be found in all the spheres of the public live.

Sphere of appearances of the mafia: 1). In the state administration, 2). In the politics, 3). In the justice system, 4). In the police, prosecutor, 5). In the public services, 6). In the private sector, 7). In the TV, radio, television, newspaper, and etc., 8). In the citizen sector.

The political, financial and weapon producer mafia is the basic reason for the beginning of the war in Iraq. 


\section{Analysis of the Model of Political Mafia all over the World}

The foundation of this operating model of political mafia principle:

Appointed by the mafia that controls a state, ministers, civil servants and others who have data and evidence of wrongdoing in their field of work, crimes in which they have passed each other and one of the mafia has helped them to pass.

These are different cases such as gross violations of tax legislation - tax evasion, concealment of profits, tax evasion, and others - ie held by the officers of the NRA and accordingly entered into force the decisions of the NRA, which

Crimes in the penal code - various offenses under the Criminal Code under which the pre-trial proceedings were discontinued.

Political mafia based on just these basic as understanding is the following:

I have appointed and appoint thy family, thy people in state structures

Preparation of contracts from the eligibility of candidates and requirements of the candidates that are so close candidate of the party man, to win the contract.

Preparing the procurement of the conditions, so that only candidate to win this contest, auction or other contract.

Political mafia mainly adopts such laws that they do not pursue relevant leaders of state structures, institutions and others. This is the guarantee of the political mafia. It creates laws to make in law violations and their crimes. To legitimize their crimes, and no problems with the justice system - the courts, prosecution, it should political mafia to appoint their relatives Chief Prosecutor for prosecutors at all levels and in all offices across the country. Political mafia appointed to positions of responsibility in the judiciary and judges loved ones to party mafia leadership positions. Of leadership positions in the courts - the final authority appointed people close to political mafia. This avoids any complaints of crimes committed by people of political mafia in the entire state. It is done at all levels of prosecution. Expressly legislate to not pursue committed by prosecutors and judges crimes mentioned in the constitution if Republic accepted that members not to pursue the commission of offenses by judges and prosecutors. This legitimized lawlessness, corruption, mafia. In the judiciary are appointed judges to serve only orders to give a judgment in favor of our person, our company. By the court and the prosecution is actually legitimize the theft of factories, companies.

By the court and the prosecution is done so that the right people, the right companies mafia in the lists of creditors are claimants and others.

By being anywhere any law of a company or person can not lead a lawsuit against prosecution for its inaction on the reluctance to reveal crimes committed by notaries, the Judges prosecutors?

By being anywhere law a company or person can not lead a lawsuit against prosecution for its inaction on the reluctance to reveal crimes committed by notaries, the Judges prosecutors of companies close to the mafia who steal targets companies with assets worth billions. This is done by pressure from internal services - police, agents, government officials and officials of the National Revenue Agency, tax offices, municipal offices.

Accepted such laws if there is an order from the Mafia to tax and other authorities, including police, the individual can not complained of any institution, structure and you state institutions.

Just political mafia secures not only institutions, government, municipal racketeering and extortion, pressure, squeezing, extortion of embarrassing, but persecution by such institutions only and only to be withdrawn illegally ownership of honest people and companies .

Political mafia all over the world works with financial institutions - banks, insurance companies, pension funds and others. There are also laws that serve the interests of these financial behemoths - banks, insurance companies, agencies, tax authorities and others. Through these financial institutions and laws to be adopted in their favor, using even the structure of enforcement, thus stealing property owned - companies, factories and others on the "inconvenient" individuals and companies. Which does not enter and is not willing to give and transfer property ownership, he is pursued by illegal means as political mafia use any structures -prokurori to raise absurd accusations that prosecutors themselves to commit crimes against civilians just to perform the contract Mafia. If the IRS can not achieve this pressure and racketeering, which lead to a positive result of the mafia, which through racketeering and extortion to perform the contract, it includes not only prosecutors to raise illegal and 
absurd accusations in making overt crimes. In extreme cases are activated state structures - police and specific individuals to perform the contract - the murder of the "inconvenient" individuals.

Only the interests of big profits in each war are the moving power to begin the war against the IRAQ.

Based on this theory of the mafia all the process made in the war against IRAQ is made by the political, financial and weapon producers mafia.

\section{Discussion and Conclusions}

The thesis of Lord Prof. Dr. Momchil Dobrev is that the real causes of the financial crisis in 2008 is the accumulated money from the profit from the sale of weapons and equipment in the war in Iraq. This thesis rests on the conclusions of Lord Prof. Dr. Momchil Dobrev based on the amount of money spent on financing the war in Iraq and the rate of profit from the sale of weapons, ammunition, equipment, war maintenance - clothing, equipment, foods.

The conclusions of Lord Prof. Dr. Momchil Dobrev rely on his experience and knowledge of the norm of profit in the trade of weapons, ammunition, food, equipment and clothing and military support in one war.

So far no one in the world has looked at the dependence of free money generated and profits on profits and the investment of these free money in construction and such derivatives and instruments.

The enormos profits for the financial institutions, producer of weapon in beginning of the war against Iraq is the reason for the financial crises in 2008 that was crises in financial, economic, producer, social, cultural spheres on the basis of the Momtchil Dobrev's "Theory of generating of crises" and the Momtchil Dobrev's "Theory of the mafia".

When certain actions and resolutions of governments, presidents, countries, financial institutions, producer of weapon to start the war against the Iraq on example who have clear and proven interest of big profits, this leads to a deep, irreversible, financial crisis, which crisis affects all circles in a society, economic, administrative health a, pension, tax, social, demographic.

All these actions are conscious and incited to the interests of financial interests of statesmen, politicians, political partiesq producer of weapon, financial institutions.

Based on the above examination, the topic and the these of Lord Prof. Dr. Momchil Dobrev has been proven.

\section{References}

Dobrev, M. (2013). Theory if degree of trust. Bulukrain-MM, Sofia, BG.

Dobrev, M. (2014). Theory of the corruption and Theory of the mafia. Bulukrain-MM,Sofia., BG.

Dobrev, M. (2015). Theory of generating of crises. Bulukrain-MM, Sofia, BG.

Dobrev, M. (2016). Is there a mafia in the European Commission and Union? Bulukrain-MM, Sofia, BG.

\section{Copyrights}

Copyright for this article is retained by the author(s), with first publication rights granted to the journal.

This is an open-access article distributed under the terms and conditions of the Creative Commons Attribution license (http://creativecommons.org/licenses/by/4.0/). 